\title{
TOLERANSI TANAMAN PENEDUH POLYALTHIA LONGIFOLIA DAN PTEROCARPUS INDICUS TERHADAP GANODERMA SP.
}

\author{
Siti Muslimah Widyastuti, Harjono, \& I Riastiwi \\ Fakultas Kehutanan Universitas Gadjah Mada \\ E-mail: smwidyastuti@ugm.ac.id
}

\begin{abstract}
Susceptibility of Urban Trees Polyalthia longifolia and Pterocarpus indicus to Infection of the red root rot fungus Ganoderma $s p$. Urban trees on the Gadjah Mada University (UGM) area play an important role in increasing environmental qualities as well as in supporting the teaching and learning processes. However, red root rot disease caused by Basidiomycete Ganoderma sp. has severely infected some existing urban trees. This experiment was aimed to determine the susceptibility of Polyalthia longifolia (glodokan) and Pterocarpus indicus (angsana) to the infection of Ganoderma sp. Identification of infected trees was performed in UGM area. Further steps were carried out to achieve those objectives : (1) isolation of Ganoderma spp. and testing of Koch's postulate and (2) examination of the susceptibility of P. longifolia and P. indicus to infection of Ganoderma sp. The susceptibility test of $P$. longifolia and $P$. indicus to Ganoderma sp. indicated that $P$. longifolia was more resistant to fungal pathogen infection than that of $P$. indicus. Based on this experiment, it can be concluded that $P$. longifolia is a species that is more suitable than $P$. indicus. P. longifolia should be planted on the areas that have been infested with inocula of Ganoderma sp..
\end{abstract}

Key words: Ganoderma, Polyalthia longifolia, Pterocarpus indicus, plant resistance

\begin{abstract}
ABSTRAK
Toleransi Tanaman Peneduh Polyalthia longifolia dan Pterocarpus indicus terhadap Ganoderma sp. Tanaman peneduh yang ada wilayah kampus merupakan salah satu faktor yang mendukung kenyamanan proses belajar mengajar. Ganoderma spp., penyebab penyakit busuk akar merah telah menyerang sebagian tanaman peneduh yang ada, karena pemilihan jenis pohon peneduh masih belum berdasarkan ketahanan terhadap serangan Ganoderma sp. Penelitian ini bertujuan untuk mengetahui kerentanan Polyalthia longifolia (glodokan) dan Pterocarpus indicus (angsana) terhadap Ganoderma sp. isolat kampus UGM. Untuk mencapai tujuan tersebut, dilakukan: (1) mengisolasi penyebab penyakit dan uji Postulat Koch, serta (2) uji kerentanan P. longifolia dan P. indicus terhadap isolat Ganoderma sp. Hasil Uji kerentanan P. longifolia dan P. indicus terhadap Ganoderma sp. membuktikan bahwa P. longifolia lebih tahan terhadap infeksi Ganoderma sp. dibandingkan $P$. indicus. Hasil ini merupakan indikator awal $P$. longifolia adalah jenis yang lebih sesuai sebagai pohon peneduh dibandingkan $P$. indicus, terutama pada lokasi-lokasi yang telah diketahui mengandung sumber inokulum Ganoderma sp.
\end{abstract}

Kata kunci: Ganoderma, Polyalthia longifolia, Pterocarpus indicus, ketahanan tanaman

\section{PENDAHULUAN}

Hutan kota merupakan kumpulan pepohonan yang menciptakan iklim mikro yang disusun diantaranya oleh pohon-pohon peneduh. Hutan kota secara umum berperan sebagai penahan dan penyerap partikel timbal, peredam kebisingan, penahan angin, mengurangi bahaya hujan asam, penghasil oksigen, $\mathrm{CO}$, dan $\mathrm{CO}_{2}$ serta meningkatkan keindahan (Dahlan, 1992). Beberapa jenis pohon peneduh yang sering digunakan antara lain Pterocarpus indicus (angsana), Polyalthia longifolia (glodokan), Dalbergia latifolia (sonokeling), Delonix regia (flamboyan), dan Acacia spp. (akasia).
Pohon peneduh di wilayah kampus Universitas Gadjah Mada khususnya Acacia spp. banyak yang mati terkena penyakit busuk akar merah yang disebabkan oleh jamur Ganoderma spp. Satu demi satu tanamantanaman tersebut mengalami kerusakan dalam waktu yang tidak sama dan berlangsung cukup lama. Hal ini menandakan penyakit busuk akar merah sudah ada sejak lama di lokasi tersebut. Kematian yang tidak serempak disebabkan sifat infeksi patogen yang lambat dan laten (Widyastuti et al., 1998b).

Penyakit busuk akar merah dikenal sebai penyakit yang merugikan tanaman perkebunan dan kehutanan. Tanaman perkebunan yang rentan terhadap serangan Ganoderma sp. antara lain Hevea brasiliensis (karet), 
Elaeis guinensis (kelapa sawit), Camellia sinensis (teh), Theobroma cacao (kakao), dan Persea americana (alpokat) (Semangun, 2000). Beberapa tanaman kehutanan yang diketahui rentan selain Acacia spp. adalah Casuarina equisetifolia (cemara udang), Paraserianthes falcataria (sengon), jenis-jenis Eucalyptus spp. (eukaliptus), dan Tamarindus indica (asam jawa) (Widyastuti et al., 1998b).

Kematian pohon peneduh menyebabkan kerugian yang cukup besar. Pohon peneduh yang tumbang merusak fasilitas umum seperti kabel telepon dan pagar (Gambar 1), dan dapat mencelakakan orang. Di lain pihak, aspek kesehatan tanaman peneduh dalam pengelolaannya masih kurang diperhatikan. Oleh sebab itu diperlukan penelitian mengenai tingkat kerentanan pohon peneduh berdasarkan jenisnya.

\section{METODE PENELITIAN}

Isolasi Ganoderma sp. Ganoderma sp. diisolasi secara aseptis dengan langkah-langkah sebagai berikut (Widyastuti et al., 1998a): (1) tubuh buah segar dipotong melintang atau rhizomorf diambil miselianya dengan menggunakan skalpel, (2) tubuh buah atau rhizomorf diambil sebagian kecil sampel jaringannya menggunakan pinset (3) sampel disterilkan dengan cara dicelupkan dalam Sodium hipoklorit 2,5\% selama 30 detik kemudian dicelupkan etanol 70\% selama 30 detik, (4) sampel dicuci dua kali menggunakan air steril, dikeringkan dengan kertas saring dan dipindahkan secara aseptis pada medium Potato Dextrose Agar (PDA). Isolat yang diperoleh disimpan dan diperbanyak pada PDA miring. Uji Postulat Koch dilakukan untuk mengetahui apakah jamur yang didapatkan merupakan organisme penyebab penyakit. Pada uji ini Crotalaria sp. digunakan sebagai tanaman indikator (Semangun, 2000). Ganoderma sp. yang sebelumnya telah ditumbuhkan pada potongan akar A. mangium dengan diameter $\pm 1 \mathrm{~cm}$ dan panjang \pm 3 $\mathrm{cm}$ selama 2 minggu, diinokulasikan pada semai Crotalaria sp. dengan posisi inokulum menempel pada pangkal batang. Reisolasi penyebab penyakit dilakukan dengan mengisolasi patogen dari pangkal batang Crotalaria sp. yang telah menunjukkan gejala dan tanda (Widyastuti et al., 1998b).

\section{Respon Polyalthia longifolia dan Pterocarpus} indicus terhadap Ganoderma sp. Untuk mengetahui respon tanaman terhadap Ganoderma sp., dilakukan inokulasi Ganoderma sp. pada semai $P$. longifolia dan $P$. indicus yang berumur 3 bulan. Ganoderma sp. ditumbuhkan pada potongan akar A. mangium selama 2 minggu sebagai sumber inokulum. Inokulasi dilakukan dengan cara menempelkan inokulum Ganoderma sp. pada pangkal batang tanaman dan diinkubasikan di tempat yang lembab dan teduh selama 48 minggu. Tanaman diamati gejala dan tandanya pada akar dan bagian pangkal batang untuk mengetahui terjadi tidaknya infeksi oleh jamur Ganoderma sp., misalnya saat daun mulai menguning dan rontok serta muncul miselium jamur Ganoderma sp. pada pangkal akar.

\section{HASIL DAN PEMBAHASAN}

Uji Postulat Koch. Pada minggu keenam setelah inokulasi Crotalaria sp. terdapat rhizomorf pada leher akar dan perakaran, serta tanaman uji mulai menunjukkan gejala kematian berupa layu (Gambar 2B dan 2C). Reisolasi rhizomorf jamur patogen dari leher akar

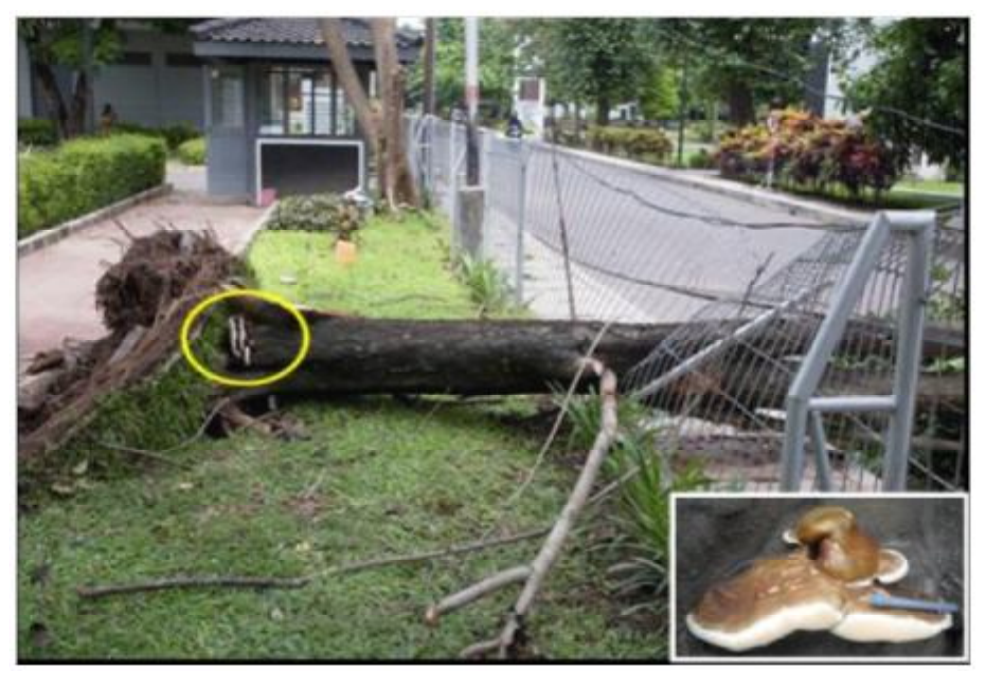

Gambar 1. Kerusakan Pterocarpus indicus akibat serangan Ganoderma sp. di kampus UGM. 

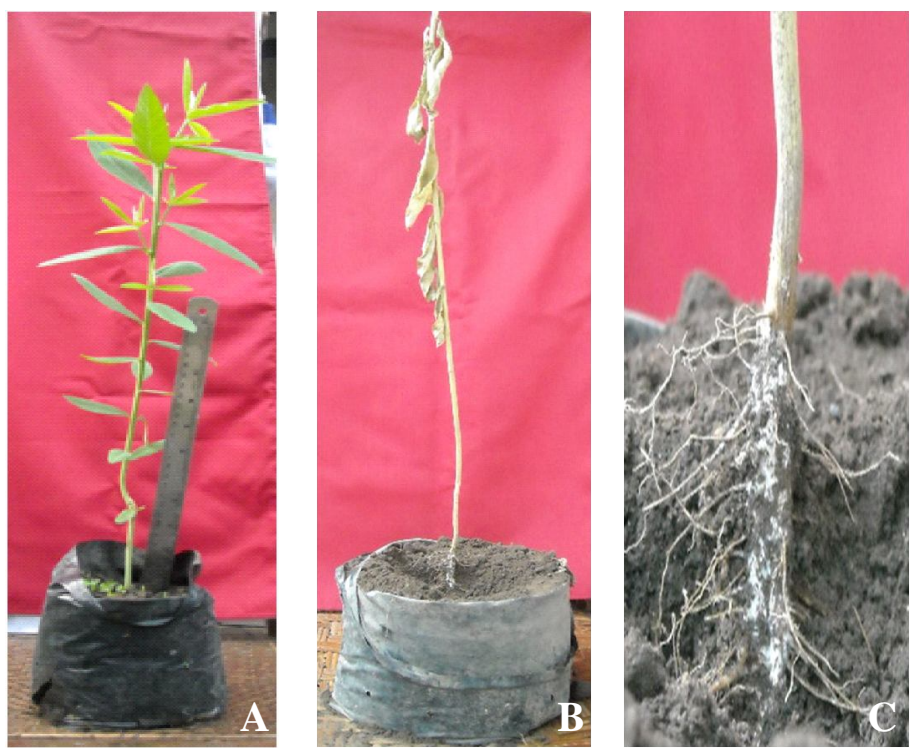

Gambar 2. Uji Postulat Koch Ganoderma sp. menggunakan tanaman indikator Crotalaria sp.. (A) Kontrol, (B) Diinokulasi dengan Ganoderma sp. (C) Rhizomorf jamur patogen pada pangkal batang dan perakaran.

Crotalaria sp. menunjukkan morfologi koloni yang sama dengan biakan murni Ganoderma sp. yang sebelumnya telah diinokulasi ke Crotalaria sp.

Toleransi Polyalthia longifolia dan Pterocarpus indicus terhadap Ganoderma sp. Selama 8 minggu setelah diinokulasi Ganoderma sp., semai P. indicus menunjukkan bahwa rhizomorf jamur patogen sudah terbentuk pada leher akar dan perakaran semai $P$. indicus, tetapi tanaman belum menunjukkan gejala kematian/layu (Gambar 3A). Kerusakan belum terlihat pada irisan penampang melintang akar. Penampang melintang akar pada perlakuan kontrol tidak terdapat kerusakan (Gambar 3B).

Semai $P$. longifolia setelah dinkubasi selama 48 minggu dengan Ganoderma sp. menunjukkan bahwa tanda rhizomorf jamur patogen sudah mulai terbentuk pada leher akar semai, meskipun demikian belum dijumpai gejala penyakit busuk akar merah pada tanaman (Gambar 4A dan 4B). Semai P. longifolia masih tampak sehat meskipun terdapat miselium Ganoderma sp..

Pada penampang melintang akar P. longifolia terdapat perubahan warna dari putih menjadi cokelat kehitaman sebesar $80 \%$ dari total luas permukaan penampang melintang akar (Gambar 4B). Perubahan warna dari putih menjadi cokelat kehitaman pada penampang melintang akar diduga merupakan akibat senyawa fenolik sebagai respon terhadap infeksi Ganoderma sp. yang diinokulasikan pada semai tersebut. Perubahan warna pada perlakuan kontrol ditandai dengan warna hitam yang disebabkan luka sayatan. Respon dari semai terhadap luka sayatan sebesar 20\% dari total luas permukaan akar karena tidak terjadi infeksi patogen (Gambar 4D).

Respon tanaman terhadap infeksi patogen dapat bermacam-macam. Sebagian besar tanaman menghasilkan senyawa fenolik dan turunannya yang beracun sehingga dapat menghambat pertumbuhan patogen (Lattanzio et al., 2006). Senyawa fenolik yang secara alamiah sudah terdapat di dalam tanaman, jumlahnya akan bertambah jika ada rangsangan berupa infeksi patogen. Banyak enzim yang bertindak sebagai katalis dalam proses biosintesis senyawa fenolik, diantaranya phenolases, phenoloxidases, polyphenoloxidases. Senyawa kinon mengalami polimerisasi membentuk pigmen berwarna cokelat kehitaman pada jaringan tanaman (Pandey, 2006). Dari penjelasan tersebut diduga warna coklat merupakan senyawa fenolik yang teroksidasi sebagai respon tanaman terhadap infeksi Ganoderma sp.

Tingkat kerentanan $P$. longifolia dan $P$. indicus terhadap penyakit busuk akar merah menunjukkan bahwa $P$. indicus lebih rentan terserang Ganoderma sp. dibandingkan $P$. longifolia. Hal ini terlihat dalam waktu 8 minggu pada $P$. indicus muncul tanda rhizomorf patogen, sedangkan pada $P$. longifolia rhizomorf baru muncul 48 minggu setelah inokulasi (Tabel 1). Pterocarpus indicus diduga merupakan inang salah satu dari jamur Ganoderma sp. sehingga $P$. indicus lebih rentan terhadap serangan Ganoderma sp. Hasil penelitian ini sesuai dengan peneliti terdahulu (Hennesy 

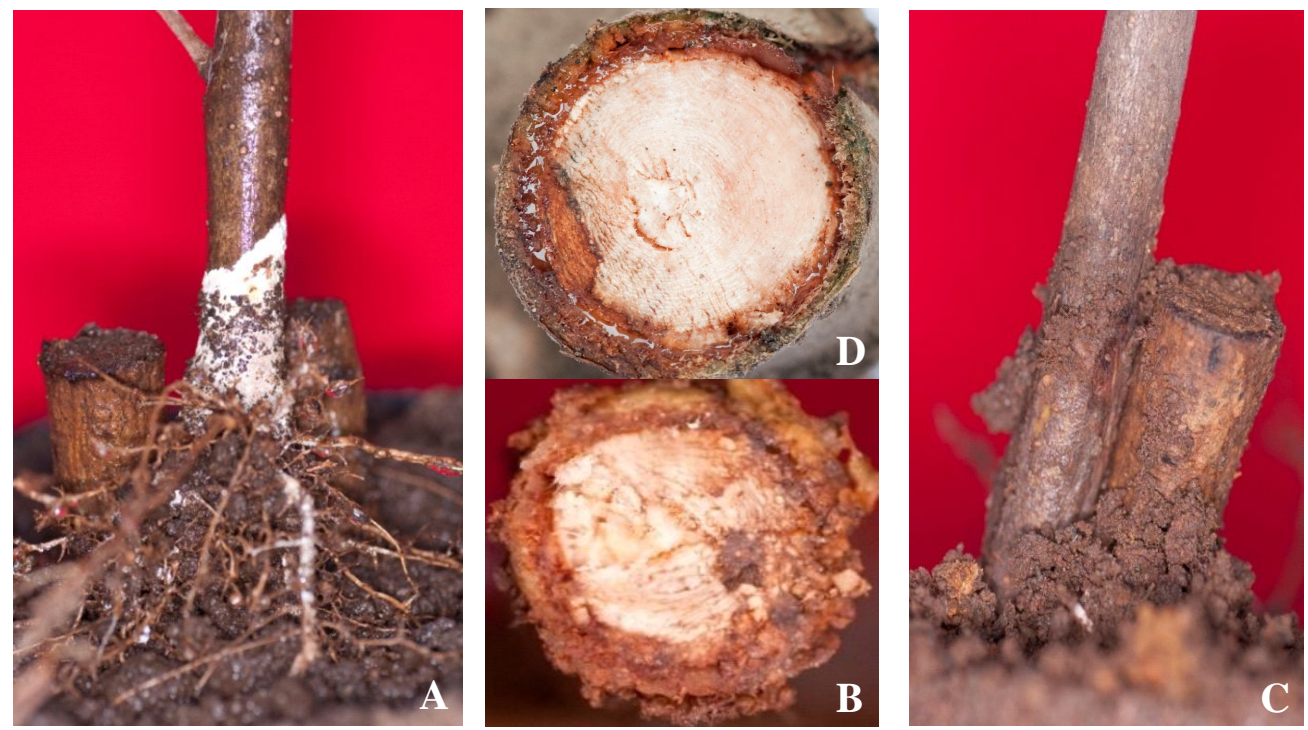

Gambar 3. Respon toleransi semai Pterocarpus indicus terhadap Ganoderma sp. isolat GD $\mathrm{TP}_{2} 8$ minggu setelah inokulasi. (A) rhizomorf, (B) penampang melintang dan perlakuan kontrol, (C) rhizomorf, dan (D) penampang melintang.
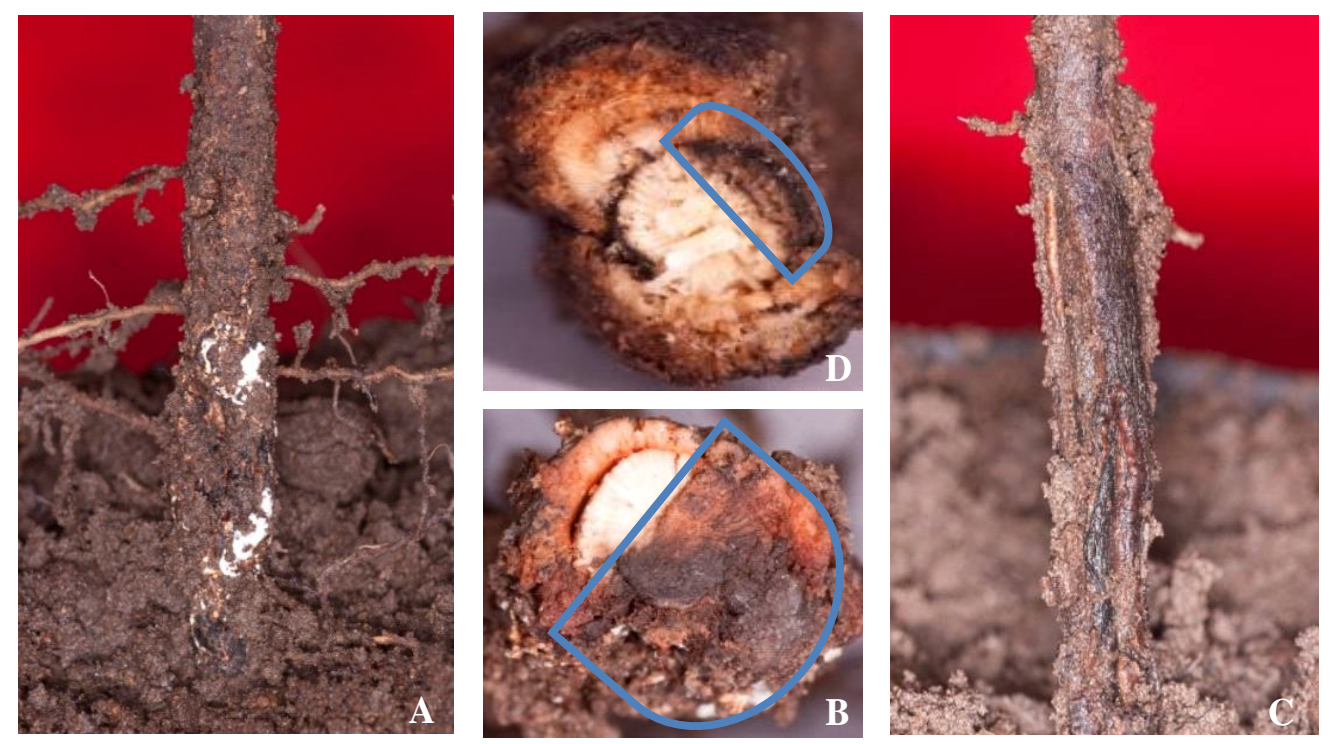

Gambar 4. Respon toleransi semai Polyalthia longifolia terhadap Ganoderma sp. isolat GD $\mathrm{TP}_{2} 48$ minggu setelah inokulasi. (A) rhizomorf, (B) penampang melintang dan perlakuan kontrol, (C) rhizomorf, dan (D) penampang melintang.

\& Daly, 2007) yang menyatakan bahwa $P$. indicus rentan terhadap penyakit busuk akar merah, meskipun sampai saat ini masih belum ada pustaka yang melaporkan bahwa di Indonesia sudah terjadi serangan Ganoderma sp. pada $P$. indicus. Reaksi senyawa fenolik sebagai respon ketahanan tanaman tidak muncul pada $P$. indicus dibandingkan $P$. longifolia yang menimbulkan reaksi senyawa fenolik.
Pada tanaman Acacia spp. di kawasan kampus UGM penyakit busuk akar yang disebabkan oleh jamur Ganoderma sp. menyerang dengan intensitas serangan yang cukup bervariasi. Widyastuti et al. (1998b) melaporkan intensitas serangan pada A. auriculiformis, A. mangium, A. oraria, dan A. crassicarpa secara berurutan masing-masing sebesar 38,59; 22,22; 28,95 dan $66,67 \%$. Lokasi tanaman-tanaman tersebut dikhawatirkan merupakan akumulasi sumber inokulum 
Tabel. 1. Gejala yang muncul setelah inokulasi (minggu)

\begin{tabular}{lcccc}
\hline \multirow{2}{*}{ Jenis tanaman } & \multicolumn{3}{c}{ Lama inokulasi (minggu) } \\
\cline { 2 - 5 } & 6 & 8 & 48 \\
\hline Crotalaria sp & +++ & +++ & mati \\
Pterocarpus indicus & - & +++ & ++++ \\
Polyalthia longifolia & - & - & + \\
\hline
\end{tabular}

(-) miselium tidak muncul dan (+) miselium yang mucul.

jamur Ganoderma sp. yang semakin lama potensi jamur dalam menyerang tanaman semakin tinggi. Akibatnya rotasi tanam berikutnya akan mengalami gangguan pada umur pohon yang ditanam akan semakin singkat. Ada kemungkinan Ganoderma sp. dapat menginfeksi pohon peneduh yang ditanam sebagai pohon pengganti Acacia spp.

Keberadaan Ganoderma sp. di wilayah kampus UGM pada tahun 2000-an sudah pada tahap yang mengkhawatirkan sehingga banyak dilakukan penggantian jenis-jenis pohon peneduh. Pohon peneduh yang ditanam pada waktu itu diantaranya $P$. indicus (angsana), Samanea saman (trembesi), Mimusops elengi (tanjung), P. longifolia (glodokan), dan Delonix regia (flamboyan). Akan tetapi tanaman tersebut belum terbukti tahan terhadap patogen busuk akar merah, karena masih banyak terjadi kerusakan yang mengakibatkan pohon inang tumbang (Gambar 1).

Salah satu syarat pemilihan jenis penyusun hutan kota adalah pohon yang tahan terhadap hama dan penyakit (Fandeli et al., 2004; Zoer'aini, 2005). Karena $P$. longifolia lebih tahan terhadap serangan patogen busuk akar merah daripada $P$. indicus, maka $P$. longifolia merupakan salah satu jenis pohon peneduh yang dapat direkomendasikan untuk ditanam di hutan kota.

\section{SIMPULAN}

Polyalthia longifolia lebih tahan terhadap Ganoderma spp. daripada Pterocarpus indicus. Oleh karena itu dibanding $P$. indicus, $P$. longifolia lebih direkomendasikan menjadi pohon peneduh alternatif yang dapat ditanam di wilayah yang sebelumnya telah terdapat inokulum Ganoderma sp.

\section{SANWACANA}

Terima kasih pada Tanoto Foundation yang telah memberikan dana penelitian kepada penulis pertama. Penelitian ini merupakan bagian dari tugas akhir penulis ketiga. Paper ini telah dipresentasikan pada Seminar International IUFRO "The Impact of Climate Change to Forest Pest dan Diseases in the Tropics, Yogyakarta, 8-10 Oktober 2012.

\section{DAFTAR PUSTAKA}

Dahlan EN. 1992. Hutan Kota: Untuk Pengelolaan dan Peningkatan Kualitas Lingkungan Hidup Asosiasi Pengusaha Hutan Indonesia. (APHI). Jakarta.

Fandeli C, Kaharudin, \& Mukhlison. 2004. Perhutanan Kota. Gadjah Mada University Press. Yogyakarta.

Hennesy C \& Daly A. 2007. Ganoderma Diseases. http:// www.nt.gov.u/dpifm. Download: 1 Februari 2010.

Lattanzio V, Lattanzio VMT, \& Cardinali A. 2006. Role of Phenolics in the Resistance Mechanisms of Plants Against Fungal Pathogens and Insects. Phytochemistry. 23-67.

Pandey BP. 2006. Plant Pathology (Pathogen and Plant Diseases). S. Chand \& Company Ltd. New Delhi.

Semangun H. 2010. Penyakit - Penyakit Tanaman Perkebunan di Indonesia. Gadjah Mada University Press. Yogyakarta.

Widyastuti SM, Sumardi, \& Hidayati N. 1998a. Kemampuan Trichoderma spp. untuk pengendalian jamur akar putih pada Acacia mangium secara in vitro. Buletin Kehutanan 36: $15-22$.

Widyastuti SM, Sumardi, Sulthoni A, \& Harjono. 1998b. Pengendalian Hayati Penyakit Akar Merah pada Akasia dengan Trichoderma. Jurnal Perlindungan Tanaman Indonesia 4: 65-72.

Zoer'aini DI. 2005. Tantangan Lingkungan dan Lansekap Hutan Kota. PT. Bumi Aksara. Jakarta. 